\title{
Michaela DITRICHOVÁ
}

\section{LÁSKA NA JEDNU NOC V POLSKÉM FILMU 60. LET}

\author{
One Night Love in Polish Cinema in the'60s
}

Keywords: Poland, cinematography, one night love

Contact: Univerzita Pardubice; misaditrichova@gmail.com

\section{Úvod}

Motiv vztahu na jednu noc, potažmo sexu na jednu noc, je v současné filmové tvorbě naprosto obvyklým jevem. Tento námět můžeme najít snad v každém filmovém žánru od oskarových snímků, až po „béčkové“ televizní komedie. Pokud se ve filmu objeví scéna, která zobrazuje sexuální styk v jakékoliv možné situaci, nejen že tato podívaná diváka nepřekvapí, ale neudiví ho, ani pokud se bude jednat o hlavní téma filmu, na nějž je navázán celý děj. Ve svém článku se budu věnovat tomuto motivu a jeho zpracování v polských filmech z období 60. let. Během vybraného desetiletí se premiéry dočkalo téměř 300 různých filmů. $Z$ nich jsem vybrala a analyzovala několik, v nichž se vybraný motiv objevuje. ${ }^{1}$ Prezentovaná analýza spočívá především v metodě komparace filmových děl ${ }^{2}$ a sledovaní motivu lásky na jednu noc $\mathrm{s}$ jeho různými specifikami a proměnami. Výsledkem je rozdělení filmů podle do čtyř kategorií, dle způsobu, jakým si tvůrci s námětem poradili a jak ho zobrazili: první kategorí je láska na jednu noc ve formě manželské nevěry; druhou kategorií je láska na jednu v podobě dobrodružství; ve třetí jsou zařazeny filmy komediální se specifickým přístupem k motivu; poslední filmy zobrazují lásku na jednu noc jako emocionální cit, a nikoliv sexuální akt.

V období po druhé světové válce se kino stalo žádanou formou zábavy, způsobem, jak uniknout poválečné realitě a dle sociologa Kazimierza Żygulskiého bylo také zrcadlem, odrážejícím realitu ted' a tady, bylo malým obrazem světa, jak píše ve svém článku. ${ }^{3}$ Po roce 1945 došlo k znárodnění kinematografie a v Polsku vznikl státní podnik Film Polski, který měl pod kontrolou veškerou filmovou tvorbu ve všech jejích

\footnotetext{
${ }^{1}$ Do analýzy nebyly zařazeny krátkometrážní, válečné a historické filmy, nebot' jejich zpracování a přístup $\mathrm{k}$ filmům tohoto druhu je specifický a již svým žánrem jsou předurčeny $\mathrm{k}$ využívání schémat, která ovlivňují veškerá konání hlavních hrdinů.

${ }^{2}$ Názvy filmů jsou uváděny v polské originále, pokud se filmy dostaly do české produkce, je uváděn český název.

${ }^{3}$ Żygulski, K. Kultura filmova w Polsce. Kino. 1970 (7).
} 
úrovních. V Polsku sice v roce 1946 nevznikl ani jeden film, ale v dalších letech začala produkce růst, a $v 60$. letech bylo polským divákům představováno od dvaceti po rekordních čtyřicet pět filmů ročně. $V$ poválečném čtvrtstoletí se jednalo především o filmy s válečnou tématikou, filmy psychologické, pojednávající o lidských osudech poznamenaných válečným obdobím, filmy budovatelské a stále populárnějšími se stávaly také komedie. Kromě filmových pláten se od roku 1957 dostává film v Polsku i do domácností občanů prostřednictvím televizních obrazovek, což je obrovským posunem ve vývoji nejen kinematografie, ale především jejího vnímání. ${ }^{4}$ Poté co se v Polsku k moci dostala komunistická strana, která uplatňovala své postupy i ve filmovém prostředí, začala se kolem krku polské kinematografie pomalu utahovat smyčka cenzury. Prvním mezníkem se stal Zjazd filmowy w Wiśle, který se konal v roce 1949. Na sjezd se dostavilo více než 200 účastníků, režiséři však byli pozváni pouze třii. ${ }^{5}$ Na sjezdu byl především zdůrazněn prim scénáře, a hlavním požadavkem se stalo chápání režiséra pouze jako tvưrce obrazové stránky literárního díla, jímž je psaná předloha. Scénář se tak stal v procesu tvorby důležitějším, než samotný film. Již v prosinci 1949 vznikla Centralna Międzyorganizacyjna Komisja Repertuarowa, představující oficiální cenzurní dozor nad veškerou uměleckou tvorbou a jejímž úkolem bylo vyřazovat z produkce všechna potencionálně škodlivá díla, a také tvůrcům dávat doporučení ohledně tématiky a zpracování. Zároveň vznikla cenzorská instituce Komisja Ocen scenariuszy i Filmów a tvưrci byli nuceni pro všechny filmy, které měly být natočeny, nejprve získat souhlas se scénářem. Ten samozřejmě musel odpovídat požadavkům strany. Témata se měla nést $\mathrm{v}$ duchu marxismu a leninismu, a docházelo i k většímu dohledu nad šířením zahraničních filmů.

V roce 1956 politická cenzura lehce povolila, nebot' i do polských kruhů se dostala diskuze spojená s referátem Nikity Chruščova o kultu osobnosti. Přestože komunistická strana stále držela kulturní branži pevnou rukou, došlo ke zmírnění cenzury a jedním z výsledků této oblevy byl vznik tzv. Polské filmové školy ${ }^{6}$. V jejím duchu se neslo celé období mezi lety 1956-1961.7 Rozvoj nového proudu polské kinematografie skončil s vydáním Uchwaty Sekretariatu KC PZPR w sprawie kinematografii v roce $1960 .{ }^{8} \mathrm{~V}$ byly zkritizovány filmy Polské filmové školy, jež se dle jejích měřítek neslučovaly s oficiální historiografií. Doporučila režisérům, scénáristům a dalším tvůrcům, aby se věnovali tématům historickým, především válečné nebo

\footnotetext{
4 Tamtéž, s. 41-49.

${ }^{5}$ Madej, A. Zjazd filmowy w Wiśle, czyli dla każdego coś przykrego. Kwartalnik filmowy. 1997 (18), s. $207-214$.

${ }^{6}$ Jednalo se o tvorbu mladých režisérů narozených ve 20. letech, mezi které patřili především studenti Państwowej Wyższej Szkoły Filmowej w Łodzi, např́iklad Andrzej Wajda, Wojciech Jerzy Has, Andrzej Munk, Kazimierz Kutz či Tadeusz Konwicki.

${ }^{7}$ Misiak, A. Cenzura filmowa po zjeździe w Wiśle. Kwartalnik Filmowy. 2003 (43), s. 93-102.

${ }^{8}$ Lubelski, T. Polska Szkola Filmowa. Encyklopedia kin. Kraków, 2003.
} 
okupační tématice, boji s fašismem či zobrazování sovětských hrdinů. Ministr kultury a umění Tadeusz Galiński ve svém proslovu při poradě filmových tvůrců výrazně doporučil tvořit filmy, které budou vychovávat a učit společnost o opravdových neprátelích státu. Kinematografie se měla stát především výchovným nástrojem propagandy a témata musela být shodná s politikou strany. ${ }^{9}$

\section{Milostné dobrodružství jako způsob pomsty}

Pod slovním spojením „láska na jednu noc“, si většina lidí pravděpodobně představí milostné nebo erotické dobrodružství, které začíná večer a končí ráno, když se účastníci rozloučí s vědomím, že se již nikdy nesetkají. Jinak řečeno - jednorázovou sexuální záležitost. Kromě tělesné touhy a erotické přitažlivosti mezi dvěma osobami, nás jako další ve spojitosti se sexem na jednu noc, může napadnout nevěra, která jde často ruku $\mathrm{v}$ ruce s jednorázovým sexuálním zážitkem. Podvod partnera je s milostným dobrodružstvím na jednu noc často propojen a zároveň využíván ve filmovém ztvárnění, stejně jako všechny jiné lidské poklesky. Polský film v tomto není výjimkou. Ve filmech z 60. let vybraných $\mathrm{k}$ analýze se jedná o první z důležitých kategorií, do nichž lze zařadit filmové zpracování lásky na jednu noc. Ukázkovým př́íladem filmu, ve kterém dochází k manželské nevěře, a je pro celkové vyznění snímku klíčová, je Nưž ve vodě, první dlouhometrážní film Romana Polańského z roku 1961. Děj filmu se odehrává na plachetnici, již vlastní mladý manželský pár. Ten cestou do př́stavu nabere stopaře, jemuž během jízdy manžel Andrzej nabídne, aby strávil den a noc s nimi na lodi. Již od začátku filmu působí manžel spíše nesympaticky, peskuje manželku i hosta, oběma radí, téměř diktuje, co a jak mají dělat, a divákovi je jasné, že mladého cestovatele pozval jen, aby se před ním mohl předvádět, vyprávět historky z války a poučovat. Mladík se na oplátku chová velice nedospěle až protivně, znuděně a nechává se manželem vyprovokovat ke slovním přím a soutěžení různého druhu. Ženská postava jménem Krystyna se většinu filmu chová stereotypně žensky - stará se o jídlo, rutinní práce na lodi, téměř nemluví a nezasahuje do děje, chová se $\mathrm{k}$ oběma mužům až mateřsky a uklidňuje situaci, pokud se při diskusi příliš rozvášní. Děj se točí kolem soupeření mužských postav, jehož se manželka neúčastní. Více dynamiky získává děj druhý den, kdy mladý stopař hledá nůž, s nímž si předešlý den pohrával a vystavoval na odiv. Když v noci spal, manžel-kapitán nůž vzal a odmítá ho vrátit. Dochází k rvačce a mladík, který dř́ve již několikrát zmiňoval, že neumí plavat, padá do vody. Andrzej mu sice nevěřil, ale ted' začíná „ztrácet nervy“. Manželka skáče do vody a hledá stopaře, který mezitím zmizel kdesi ve vodě, ale nemůže ho najít. Doplave k bójce, a za ní posléze i manžel.

\footnotetext{
${ }^{9}$ Białous, M. Spoleczna konstrukja filmów historycznych. Pamięć zbiorowa i polityka pamięci w kinematografii polskiej 1920-2010 (doktorská práce). Uniwersytet w Białymstoku, 2015.
} 
Ukazuje se, že mladík, který o svém neplavání lhal, se stř́davě schovává pod vodou, aby ho dvojice nemohla zahlédnout. Manželský pár se nakonec vrací se na lod' a dochází $\mathrm{k}$ hádce, jak dále postupovat - manžel chce hodit stopařovi věci do vody a tvářit se, že se nic nestalo. Žena nesouhlasí, vyčítá mu chování z předchozího dne a vykřikuje, že zabil člověka. Poté co na ni sprostě křičí, skáče Andrzej do vody a plave ke břehu. Krystyna zůstává na lodi sama a pláče, poté se suší a zůstává sedět na palubě. Mezitím $\mathrm{k}$ lodi připlave mladík a leze na palubu. Krystyna mu nejdříve vrazí facku, ale rychle se uklidní a vede s ním rozhovor o osobních tématech. Nakonec se i stopař převléká do suchého a v následující scéně se manželka a mladík políbí, po čemž vidíme dlouhé záběry vody. $Z$ kontextu je očividné, že došlo $k$ sexu, oba se ale chovají jako by se nic nestalo. Poté plují ke břehu, kde mladík vysedá a ona sama jede do prŕstavu, kde na ni už čeká manžel. Ani tentokrát, stejně jako v celém filmu, mezi manželským párem neproběhne žádný náznak citů či emocí - manželé pokračují v lodní rutině. Následně vidíme dvojici v autě cestou domů. Andrzej je rozhodnut jet na policii, nebot' netuší, že se mladík neutopil. Krystyna se ptá manžela, zda se bojí zatčení, a on přitakává. Manželka mu poté říká, at' se vrátí, nebot' stačí, že se bojí. Poví manželovi o všem, co se stalo a přiznává se mu k nevěře. Andrzej jí ale odmítá věřit. Výsledkem celého konfliktu je fakt, že Krystyna získává nad manželem psychickou převahu. Pro manžela existují jen dvě možnosti - bud' manželka lže a on zabil člověka, nebo mu říká pravdu a v tom př́ípadě ho podvedla. Konec filmu zůstává otevřený a nevíme, zda se manželé vydali na policii či domů. Důležitý je ale motiv oné převahy nad manželem. Ze strany manželky tedy byla motivem $\mathrm{k}$ nevěre a sexu na jednu noc možnost pomsty a nástroj, jak ublížit panovačnému muži.

Stejný motiv využil i režisér Jerzy Kawalerowicz ve svém filmu $\mathrm{Hra}(\mathrm{Gra})$ z roku 1968. Ve filmu sledujeme prŕběh dvou manželů, kteř́ jsou ve svém svazku viditelně nešt’astní. Celý film je prolnut úryvky vzpomínek na jejich vztah, dávné začátky, fázi zamilování se a různé št’astné, a posléze i nešt'astné momenty či stížnosti hrdinů na to, jak jsou nespokojení a jak se ten druhý o svou polovičku nezajímá. Bud’ se jedná o retrospektivní scény, nebo vnitřní monology hrdinů. Hned na začátku filmu zjištujeme, že manželka je architektkou a ve svém ateliéru flirtuje s kolegou z práce a žádá ho, aby ji políbil. Manžel, který je jindy velice zaneprázdněný, na ni čeká po práci, což v ní vyvolává nespokojenost. Manžel žárlí, stěžuje si, že je osamělý a má těžký život, ona mu na oplátku vytýká neustálou kritiku její osoby. K rozvoji děje dochází, když se manželé vrací autem z lovu a žena po hádce ohledně jeho nebezpečně rychlé jízdy vystoupí. Stopne si náhodného řidiče, který ji vezme na svatbu svých přátel. Žena se svým novým známým tančí, pije, později se políbí a viditelně se schyluje k erotickému sbližení. Manželka se však na poslední chvíli rozmyslí a uteče 
s odůvodněním, že to nemůže udělat. Ze svatby ji druhý den vyzvedá manžel a ona mu vypráví o svém svatebním zážitku. Je veselá a št’astná, on ji ovšem opět uráží. Žena pravděpodobně doufala $\mathrm{v}$ usmíření, ke kterému ovšem nedochází. Zamyká proto nadávajícího manžela $\mathrm{v}$ garáži a odchází. $\mathrm{V}$ další scéně vidíme, jak nasedá na motorku mladíka, kterého jsme mohli spatřit už v úvodu filmu, když se s hlavní hrdinkou snažil flirtovat v dopravní zácpě. Žena jede k němu a dopustí se s ním nevěry. Stejně jako ve všech ostatních filmech není samotných akt soulože ukázán na kameře a pár je zobrazen až „po“ aktu. Mladík se ptá ženy, zda za ním přijde i zítra, její odpověd' je však záporná. $\mathrm{V}$ tomto prípadě se tedy stejně jako u prvního filmu jednalo o jasně jednorázovou záležitost, a můžeme si povšimnout opětovného motivu pomsty, ke které se žena uchýlila ze zoufalství nad svým manželstvím.

I pro tento film byl uplatněn motiv manželského páru, kdy žena využila nevěry a sexu na jednu noc k pomstě, přestože to nic neznamená pro další budoucnost vztahu, v němž plánuje setrvat a její city vůči manželovi se nezmění. Tento vzorec nacházíme i ve filmu Nưž ve vodě, nebot' ani zde viditelně nikdo z manželů nepomýšlí na rozvod nebo rozluku. Jednalo se jen o způsob, jak na krátký čas získat pocit nadvlády a moci v manželství, snad i pocit zadostiučinění. Tento motiv potvrzuje i sám režisér Kawalerowicz v rozhovoru pro filmový magazín Kino. ${ }^{10}$

\section{Snění a útěk od reality}

Kromě motivu pomsty a nevěry můžeme najít ve vybraných filmech také krátkodobé vztahy či vztahy na jednu noc, v nich je př́stup k tématu „snový“. Tedy takový, kdy se jedná o krátkou epizodu, př́ihodu, při níž jsou účastníci „duchem jinde“, a nenacházíme pro jejich čin žádný pragmatický důvod jako v předchozích př́ípadech. Prvním filmem, který představuje takový způsob pojetí lásky na jednu noc je film Rozstanie z roku 1963, režisérem byl Wojciech Jerzy Has a snímku dal uštěpačný podtitul „sentimentální komedie“. V tomto filmu sledujeme příběh starší ženy, herečky, žijící ve Varšavě, elegantní dámy, ale přesto moderní a svobodomyslné, která po smrti svého strýčka přijíždí do malého městečka, kde zdědila nemovitost. $V$ domě, který je předmětem dědictví, již žije společenství lidí, jež hrdinka dobře zná a bydlí v něm dlouhodobě. Po hereččině př́ijezdu se ji snaží obyvatele domu provdat, především z důvodu zachování vlastní střechy nad hlavou. Sice respektují její způsob života, ale nesouhlasí s ním. Jediné, co Magdalena chce, je vyřešit dědictví a vrátit se zpět do města. Náhodně se seznamuje s o mnoho mladším mužem, který o Magdalenu očividně stojí. Tvrdí jí, že je

\footnotetext{
${ }^{10}$ Viz celý rozhovor s režisérem: Jancki, S. Nie trzeba być konsekwentny. Z Jerzym Kawalerowiczem o Grze rozmawia Stanisław Jancki. Kino. 1969 (4), s. 12-19.
} 
parašutistou. Vůči hrdince se chová velice odvážně, a i ona k němu cítí jisté sympatie, kterým se ovšem brání. Jednoho dne jí mladík v noci vleze oknem do pokoje, Magdalena však nevypadá naštvaně a nechá mladého parašutistu, aby s ní flirtoval. Vedou spolu dvojsmyslný rozhovor, hrají spolu svádivé slovní hříčky - nakonec se políbí. Ráno se mladík budí nahý, a divákovi je jasné, k čemu během noci došlo. Mimo jiné konečně překročili hranici gentlemanství a teprve v této chvíli si pár začíná tykat. Mladík se Magdaleny ptá, zda do městečka znovu přijede, její odpovědí je však rezolutní ne. Ŕíká, že to bylo rozloučení (rozstanie), on přesto od vztahu očekává víc. Magdalena ho vyhazuje ze svého pokoje a teprve až ve chvíli, kdy mladík odchází, se ho ptá na jeho jméno. Důležitý a zároveň odlišný v tomto filmu je fakt, že již od začátku se z její strany jednalo o jednorázovou záležitost, pravděpodobně neplánovanou. Neznáme důvody, které Magdalenu přiměly $\mathrm{k}$ aktu s mladíkem, ale můžeme tušit, že se jednalo jen o dobrodružství, o kousek snění, snad rozloučení s městečkem a domem, do kterého se již nevrátí. Důležité pro tuto kategorii je také to, že ke krátké lásce na jednu noc došlo v jiném místě, než žije hlavní postava, což ještě umocňuje motiv dobrodružství či snění, jež cizí prostředí zpravidla přináší.

Druhým dílem spadajícím do této kategorie, ve kterém se opakují zmiňované znaky, je snímek Ruchome piasky Władysława Slesickeho. Dobrodružství samo o sobě tvoř́ téma celého filmu, ovšem pro jednoho z účinkujících se dostane na úplně jinou úroveň, než očekával. Otec se synem se vydávají tábořit na opuštěné místo u moře. Již od začátku víme, že muž je ženatý, nebot' mezi synem a otcem probíhá rozhovor o manželce, kterou ovšem po celou dobu filmu neuvidíme. Dvojice si uživá svého robinzonovského dobrodružství, když se v jejich dohledu objevuje hádající se mladý pár. Ukazuje se, že mladík zavezl dívku na opuštěné místo, aby ji přiměl k sexu. Otec se synem dívku „zachrání“ a pozvou k sobě k ohništi do tábořiště, kde s nimi přenocuje. Druhý den otec v nadsázce sděluje synovi, že by bylo veselým žertem, pokud by s nimi dívka zůstala a její společníci by ji nemohli najít. Není náhodou, že mladá žena je opravdu krásná a $\mathrm{k}$ tomu ještě sympatická, a otec $\mathrm{k}$ ní zaplane těžko skrývanou vášní. Nakonec s nimi dívka opravdu zůstává, což se stává trnem v oku syna, který se cítí odsunutý na „druhou kolej“. Otec a dívka si vyměňují pohledy, čas od času se náhodně dotknou, např́íklad když šplhají po skále u pláže. Tráví spolu většinu času a mnoho záběrů je věnováno prezentaci dívčiny krásy. Kamera ukazuje záběry jejího těla v plavkách, koupajícího se ve slunci, holou kůži, nohy, rty, tvář a svádivé mrkání dlouhých řas. Chlapec je však neustále nespokojen s otcovým přehlížením, a začíná docházet ke konfliktům mezi ním a dívkou i mezi ním a otcem. Nakonec žena z tábořiště odchází. Otec se synem jsou opět sami a muž navrhuje, že zajedou do vesnice. Syn říká otci, že zná pravý důvod, proč se tam chce muž vydat, je očividné, že důvodem je 
nalezení dívky. Ta se nakonec vrací do tábořiště sama od sebe a muž u ohně vede promluvu o tom, jak je to př́ijemné, když se dva vzájemně sympatičtí lidé takto náhodně setkají. Večer nastává bouřka a děj pokračuje v duchu laškovaní otce a dívky, a chlapec si stěžuje, že s ním otec nemluví, dochází k dalšímu konfliktu otce a syna. Nakonec jde dívka spát a situace se uklidňuje. Otec vysvětluje synovi, že prázdniny jsou čas, kdy se všechno ostatní nechává za sebou. Vzhledem k probíhající bouřce odchází muž zkontrolovat, zda je dívka $\mathrm{v}$ pořádku a jestli se nebojí. $\mathrm{V}$ dalším scéně je ráno a vidíme syna ztraceného v lese, kam se zatoulal, když hledal otce, protože po chlapcově probuzení nebyl ve stanu. Nakonec ho zpět do tábora zaveze mladík na motorce, který, jak se ukazuje, je př́telem dívky. $\mathrm{V}$ táboře hledá syn otce, až dojde $\mathrm{k}$ dívčině stanu, ve kterém najde otcovu čepici. Divákovi je tedy jasné, že muž strávil noc v dívčině stanu. Chlapec s motorkářem dále hledají muže s dívkou, až je nakonec spatří, jak se spolu válejí v písku na pláži. Když si jich rozjařená dvojice všimne, dívka běží k mladíkovi a nadšeně se s ním vítá. Poté, co ke skupince přichází i otec, se záběr kamery zastavuje na jeho nespokojené a rozezlené tváŕi - film končí. I v tomto filmu se jednalo o způsob útěku od reality, do níž se otec se synem nakonec musejí vrátit a na který upozorňuje sám otec, když vysvětluje synovi, jak vnímá dny letního volna. Bylo to jen krátké prázdninové dobrodružství, začínající pro dvojici otce a syna kempováním v pustině, ale pro muže se později přetransformovalo verotické smyslné dobrodružství a pomíjivou lásku. I v tomto prípadě byl vztah na jednu noc způsobem, jak se vymanit ze stereotypu a pro hlavního hrdinu chvílí, kdy mohl zapomenout na realitu. Prožití okamžiku, kousek letního snu před návratem ke všednosti a k manželce.

\section{Komedie - kapitola sama pro sebe}

Než se pustím do analýzy filmů, je třeba uvést, že zobrazení lásky na jednu noc $\mathrm{v}$ komediálních filmech je svérázné a celý př́stup $\mathrm{k}$ tomuto tématu je odlišný od ostatních zmíněných modelů, stejně jako žánr samotný. $V$ těchto filmech je sex na jednu noc, stejně jako vše jiné, brán s velkou nadsázkou a nelze v něm hledat žádný skrytý význam. Paradoxně se právě v této kategorii filmů přibližujeme současnému zacházení $\mathrm{s}$ motivem, nebot' je v ději často upozaděn a jeho prŕtomnost je brána se stejnou vážností, jako by se jednalo o vypití kávy či jízdu tramvají. Př́íkladem par excellence je film Pamiętnik pani Hanki, filmová komedie Stanisława Lenartowicza z roku 1963. Paní Hanka, hlavní postava př́běhu, je koketa, nestydí se za to, ba snad své chování ani nepovažuje za koketní a s jinými muži často laškuje i před vlastním manželem. Manžel Hanky, zahraniční diplomat, musí odcestovat na zahraniční cestu do Paříže. Mezitím, co je manžel pryč, se Hance svěří př́itelkyně, že podvedla manžela a milenec ji vydírá. Hanka se proto nabídne, že přesvědčí milence, aby dal kamarádce pokoj a vrátil dopisy, 
které jsou důkazem jejich vztahu. Mezitím Hanka koketuje s dalšími muži. Její život je plný večírků a společenských akcí. Později jde k údajnému vyděrači domů a snaží se dostat zpět zmíněné dopisy. Muž přeci jen souhlasí, že jí dopisy předá, ale potají si jeden nechá. Při rozhovoru Hanku viditelně svádí, a dokonce ji políbí, čemuž se Hanka brání. Nakonec jí vyděrač vytkne, že vše je její vina, nebot' sama přišla a provokovala ho. Přesto se Hanka rozhodne vyděračovi ještě jednou zavolat kvůli poslednímu dopisu. Následně jde již podruhé k němu do bytu, a tentokrát flirtuje i ona s ním. Stále se však snaží dostat zpět usvědčující dopis, na což muž opáčí, že už jej nemá a že si ho její přítelkyně vyzvedla. Během celého rozhovoru ji neustále svádí, ona ho zlehka nechává a zároveň trochu vzdoruje. Nakonec svolí k polibku. V další ději Hance telefonuje manžel z Paříže a sděluje jí, že se ve společenství vyslanců pátrá po jistém špehovi. Poté ve filmu následuje scéna $\mathrm{z}$ postele vyděrače, a vzhledem $\mathrm{k}$ nahotě postav je divákovi jasné, co se mezi Hankou a mužem odehrálo. Manžel své ženě sice vyčítá, že se setkává s jinými, když není doma, o její nevěře však nic netuší. Hanka hraje typickou ženskou hru, je to jeden ze stereotypů, který Hanka představuje - chová se tak, aby měl výčitky cestující manžel, který ji nechává samotnou, a ještě si dovoluje bránit jí, aby ve svém osamění trochu společensky žila. Když Hanka znovu volá svému milenci, zjevují se u dveří vyšetřovatelé $\mathrm{z}$ ambasády a ptají se, kdo volal na ono milencovo číslo. Berou Hanku na výslech a vychází najevo, že její milenec je špehem, po kterém se pátrá. Hanka proto musí s pravdou ven. Naštěstí pro ni se tato informace $\mathrm{k}$ manželovi nedostane.

Druhou filmovou komedií, tematizující lásku na jednu noc, je film Człowiek z M3 z roku 1968 režiséra Leona Jeannota. M-3 je typ bytu, o který je (stejně jako o jakýkoli jiný byt) nouze. Stojí o něj i doktor jménem Tomasz, muž středního věku, ovšem stále bydlící s matkou. Ta mu organizuje život a vzájemné soužití se pro hlavního hrdinu stává nesnesitelným. Později Tomasz príij́má telefonní hovor, v němž mu oznamují, že pro něj mají k dispozici byt. Raduje se, ale následně zjišttuje, že aby měl na byt nárok, musí být ženatý, nebot' tyto byty jsou určeny pro manželské páry. Jelikož o nové bydlení stojí a chce se vyprostit z vlivu matky, začne zběsilý lov na manželku. Aby mohl byt získat, musí uzavřít sňatek do třiceti dnů. Hned jako první kandidátka se ukáže dcera profesora z nemocnice, kterou potká, když si jde k profesorovi domů vyzvednout vědecký časopis. Atmosféra tohoto filmu je už daleko uvolněnější než v předchozích zmiňovaných filmech, nebot' dívka se mu bez skrupulí ukazuje ve spodním prádle, převléká se před ním, a také dveře otevírá v průsvitném negližé a kalhotkách. Mladá dívka je umělkyně, moderní a městská žena. Po společně stráveném dni, kdy je na první pohled patrné, že v sobě oba našli zalíbení, se vrací k ní domů a druhý den ráno se Tomek probouzí v dívčině posteli, samozřejmě bez oblečení. Problém přichází, když budoucí manželka odmítne Tomkovi přišít knoflík s výzvou, at' si jej přišije sám, 
z čehož je muž v rozpacích. Když mu poté sdělí, že i snídani má udělat on, je př́mo konsternován. Volá matce, aby se dozvěděl, jak se dělají míchaná vajíčka. Tohoto kulinářského výkonu bohužel není schopen. Po ranním fiasku od mladé ženy utíká a je si jistý, že se nejedná o jeho budoucí manželku. Druhou kandidátkou se stává farmaceutka z lékárny, která se ho snaží předělat k obrazu svému, dle předlohy bývalého manžela, jak Tomek později zjistí a následně vztah ukončí. Třetí kandidátkou je zraněná tenistka, která má také vadu - je chorobně žárlivá. Přesto ve vztahu s ní pokračuje, ale po další žárlivé scéně i tento poměr vyhodnocuje jako neadekvátní a pár se rozchází. Nakonec se dohodne se sestřičkou z práce, která ví, že jde o přidělení bytu a souhlasí se sňatkem a následným brzkým rozvodem. Ani tento svazek hlavnímu hrdinovi nevyjde, nebot' cestou na obřad uvízne ve výtahu a nestihne vlastní svatbu. Když už se Tomasz rozloučí s možností nového bytu, přichází k němu do kanceláře bývalá pacientka a protože vidí, v jakém je muž deprimovaném stavu nabídne se mu uvařit k večeři míchaná vajíčka. Ukazuje se, že se k němu žena perfektně hodí, a hned druhý den si ji bere za ženu. Byt nakonec stejně manželům není přidělen, nebot' došlo k záměně jmen. Se svou novou manželkou ovšem zůstává i bez M-3.

Jak bylo předestřeno, jedná se o filmy komediální, a tedy z podstaty lehkovážné. Tento fakt (snad) opravňuje hlavního hrdinu druhého snímku, aby během jednoho měsíce vystřídal čtyři ženy a oženil se po několikahodinové známosti. U obou zmíněných komedií je sex na jednu noc jevem, který je divákovi představován jako čin pro filmové postavy běžný a nepožaduje se po něm, aby hledal skryté významy, či odůvodnění. Prostě a jednoduše se tak děje. Přestože se jedná o podobný přístup k lásce a sexu na jednu noc, prostředí a vyznění filmů je velice odlišné především tím, v jakém období se děj odehrává. V prvním případě je to předválečný salónní život bohaté znuděné manželky, film plný kostýmů, večerních rób a večírků. Ve druhém př́ípadě mluvíme o moderním, již barevném, filmu, odehrávajícím se ve velkém městě a v moderní současnosti ${ }^{11}$. Mimo jiné obě analyzované komedie dělí doba vzniku pět let a film Człowiek z M3, byl natočen již v celkově více uvolněné společenské atmosféře.

\section{Sex nebo láska?}

Přestože slovní spojení „láska na jednu noc“ evokuje ve většině společnosti spíše erotické představy nebo jednoduše jednorázový sex, ve filmech z 60. let se objevuje ještě jeden, úplně jiný model jeho zobrazení, jež tvoří v mé analýze čtvrtou kategorii. Příkladem jsou dva filmy, ve kterých nedojde k sexuálnímu aktu, avšak dají se zařadit

\footnotetext{
${ }^{11}$ Film bychom př́stupem, postavami, dějem i vyzněním mohli srovnat s českou filmovou tvorbou režiséra Petra Schulhoffa a jeho filmům ze 70. let Zitra to roztočíme drahoušku...! nebo Hodime se k sobě, miláčku...?.
} 
do kategorie lásky na jednu noc, lásky pomíjivé, avšak netělesné. Lásky ve smyslu emocí a vzrušení, ale takové, které nebyla dána možnost se rozvinout a uvízla pouze na momentu jediné noci. Jde o filmy Andrzeje Wajdy Nevinní čarodějové (Niewinni czarodzieje) z roku 1960 a film Haliny Bielińské Sam pośród miasta z roku 1965. Oba filmy mají podobný nebo přinejmenším srovnatelný děj. V př́ípadě Nevinných čaroděju je to príběh mladého páru, on je lékařem, ona pravděpodobně studentkou. Chlapec náhodně potkává dívku a vzhledem k oboustranným sympatiím se jdou spolu projít nočním městem až dojdou do jeho bytu. U mladíka doma se odehrává většina celého filmu. Oba si vymyslí přezdívky, on Bazyli, ona Pelagia, a stráví spolu dlouhou noc, kterou celou věnují pouze rozhovoru. Jediné, k čemu dojde je krátký polibek. Je vidět, že se mezi nimi tvoří jisté napětí, jiskra a stávají se účinkujícími vzrušující, ale zároveň znervózňující hry. Během stráveného času se chlapec snaží o sblížení, nejen fyzické, ale především citové. Vždy když se zdá, že se odehraje událost, která by mohla změnit vývoj děje a posunout jejich jednonoční vztah na další úroveň, dívka mu zas a znovu uniká. Tento Wajdův film je koncertem dialogů a vzbuzuje v divákovi množství emocí, pocitů, ve starších osobách snad trochu melancholie a vzpomínek na mladistvé lásky. Ráno musí Bazyli opustit byt a po návratu zjistí, že i Pelagia odešla. Vydává se ji hledat, ale neúspěšně. Když se zklamaný vrací domů, Pelagia na něj v bytě čeká. Přestože nedošlo k žádné erotické události, je jasné, že se mezi dvojicí hrdinů vyvinul vzájemný cit, malá a krátká láska na jednu noc. Tato kategorie filmů dává pojmu „láska na jednu noc“ význam opravdu citový, a ne pouze sexuální, erotický či tělesný, jak je v dnešní době povětšinou konotován.

\section{Závěr}

Ve svém článku jsem rozdělila filmy s tématikou lásky na jednu noc do čtyř různých kategorií podle toho, jaké bylo dějové vyznění vtahů či erotických zážitků, a zda se jednalo o lásku nebo jen pouhý sex. $Z$ analýzy filmů vyplývá, že téma se vyskytuje naprríč žánry, nejčastěji však v žánru dramatu či psychologického filmu. Výjimkou jsou komedie, ve kterých tvůrci uchopili námět podstatně rozdílněji a odlehčeněji. Zajímavým poznatkem je, že ve většině filmů tvůrci vědomě či nevědomě opakovali jisté vzorce (model pomsty, model vytržení z reality, zesměšnění, touha po citu, touha po blízkosti). Zajímavým poznatkem je zjištění, že ve vybraných filmech neexistuje zobrazení lásky na jednu noc v podobě sexuálního aktu konaného jen pro samotnou tělesnou potřebu nebo fyzické uspokojení. Jedná se nejen o zajímavé, ba až o překvapivé zjištění, vzhledem k samotné podstatě zkoumané problematiky. Toto překvapení vyplývá snad $\mathrm{z}$ toho, že $\mathrm{v}$ dnešní době již divák přivykl hrdinům, jež jsou pouhými sběrateli požitků, a nezávazný vztah pro ně neznamená nic neobyčejného. Pokud tedy 
divák hledá lásku na jednu noc s hlubší podstatou než samotný erotický akt, právě ve filmech z 60. let může takové příběhy a vážnější přístup najít.

\section{Summary}

In my paper I divided the movies with the topic of "one night love" to the four categories, depending on the storyline, relationship meaning or erotic experience. If it was "love" or "one night stand" only. From the analysis, you find out, that there are the same regularly repetitive motives and formulas. The first category is sex as an act of revenge, second is sex as a dreamy adventure and third is a reflection of "one night stand" experience in comedies, which is different from other categories. The last category is "one night love" in emotional meaning with no sexual connotation.

\section{Literatura}

Białous, M. Społeczna konstrukja filmów historycznych. Pamięć zbiorowa i polityka pamięci w kinematografii polskiej 1920-2010 (doktorská práce). Uniwersytet w Białymstoku, 2015.

Jancki, S. Nie trzeba być konsekwentny. Z Jerzym Kawalerowiczem o Grze rozmawia Stanisław Jancki. Kino. 1969 (4), s. 12-19.

Lubelski, T. Polska Szkola Filmowa. Encyklopedia kin. Kraków, 2003.

Madej, A. Zjazd filmowy w Wiśle, czyli dla każdego coś przykrego. Kwartalnik filmowy. 1997 (43), s. 207-214.

Misiak, A. Cenzura filmowa po zjeździe w Wiśle. Kwartalnik Filmowy. 2003 (43), s. 93-102.

Żygulski, K. Kultura filmova w Polsce. Kino. 1970 (7). 